\title{
ANKOM - a new instrument for the determination of fat in muscle and meat cuts - a comparison
}

In memory of Prof. Dr. Dr.h.c. Klaus Ender

\begin{abstract}
The objective of this study was to compare the new fat extraction equipment $\mathrm{ANKOM}^{\mathrm{XT15}}$ Extractor with different chemical and physical methods which are widely used to determinate the fat content of different animal tissues. In total 23 pigs and 19 cattle were included in the investigations. Different cuts of the carcasses like longissimus muscle (MLD), head, belly and breast, feet, ham, neck, loin, tenderloin and subcutaneous fats were used for this comparison. The investigation compared following three chemical methods: classic Soxhlet method, automatic fat extraction (ANKOM ${ }^{\mathrm{XT15}}$ Extractor), automatic fat extraction following hydrolysing (ANKOM ${ }^{\mathrm{HCL}}$ Hydrolysis System, ANKOM ${ }^{\mathrm{XT} 15}$ Extractor) and two physical methods: Infratec1255 Food and Feed Analyzer and FoodScan ${ }^{\mathrm{TM}}$ Lab (FOSS). For accurate statistical analysis the different cuts were ordered into three fat groups. The repeatability $(\theta)$ of the chemical methods was calculated, which ranged between $0.88-1.00$. No significant differences were measured between the new tested device $\mathrm{ANKOM}^{\mathrm{XT15}}$ Extractor and the Soxhlet method. The use of the ANKOM ${ }^{\mathrm{XT} 15}$ Extractor is recommended because of the high precision, low purchase and using costs, and shorter analyses time.
\end{abstract}

Keywords: method, fat determination, comparison, ANKOM device

\section{Zusammenfassung}

Titel der Arbeit: ANKOM - ein neues Instrument zur Bestimmung von Fett im Muskel und Teilstücken im Vergleich zu anderen Methoden

Das Ziel der Untersuchung war der Vergleich der Fettextraktion aus unterschiedlichen tierischen Geweben mit einem neuen Fettextraktionsgerät $\left(\mathrm{ANKOM}^{\mathrm{XT15}}\right.$ Extractor) und unterschiedlichen klassischen chemischen und physikalischen Bestimmungsmethoden. Unterschiedliche Teilstücke (M. longissimus, Kopf, Bauch und Brust, Eisbein, Keule, Filet, Kotelett und Auflagefett) von insgesamt 23 Schweinen und 19 Rindern wurden in diesen Vergleich mit einbezogen. Untersucht und verglichen wurden drei chemische Methoden: klassische SoxhletExtraktion, automatische Fettextraktion mit ANKOM $^{\mathrm{XT15}}$ Extractor und automatische Fettextraktion mit vorgeschalteter Hydrolyse $\left(\mathrm{ANKOM}^{\mathrm{HCL}}\right.$ Hydrolysis System, $\mathrm{ANKOM}^{\mathrm{XT15}}$ Extractor) sowie zwei physikalische Meßmethoden: Infratec1255 Food and Feed Analyzer und FoodScan ${ }^{\mathrm{TM}}$ Lab (FOSS). Für die statistische Auswertung wurden die unterschiedlichen Teilstücke in drei Fettklassen unterteilt. Die Wiederholbarkeit $(\theta)$ der chemischen Methoden wurde berechnet und lag zwischen 0.88-1.00. Keine signifikanten Differenzen wurden zwischen dem neu getesteten Gerät ANKOM $^{\text {XT15 }}$ Extractor und der Soxhlet-Methode ermittelt. Die Nutzung des $\mathrm{ANKOM}^{\mathrm{XT15}}$ Extractors wird empfohlen auf Grund der guten Präzision, des geringeren Preises (Anschaffung und laufende Kosten) und der verringerten Analysendauer.

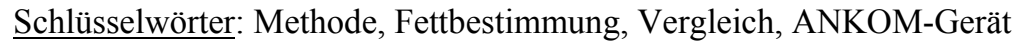

\section{Introduction}

The accurate determination of the chemical composition, including fat content of meat is very important for the efficiency of animal breeding, in food science and food industry. Fat is part of intrinsic quality of meat including palatability and sensory 
properties of meat. Intramuscular fat plays an important role for the eating quality. A high number of publications reported a closed correlation between intramuscular fat and sensory characteristics like taste, juiciness and texture. Juiciness of steer muscles increased with increasing intramuscular fat (OKUMURA et al., 2007). From morphologically point of view the term intramuscular fat covers aggregates of adipocytes in the perimysium and endomysium located as structural elements in cell membranes (ARNETH, 1998; HOHENESTER, 2006). Several authors consider that $2-3 \%$ of intramuscular fat content in meat of different domestic animals, e.g. in M. longissimus dorsi of pig as optimum (BEJERHOLM and BARTON-GADE, 1986; MEYER, 1991; LÜTJES and KALM, 1995; SEUSS-BAUM, 1998; HOHENESTER, 2006). However, optimum level of intramuscular fat may be varying across consumers and geographical regions (PIPEK et al., 2004). Consequently, objective methods are needed to quantify the intramuscular fat in meat with high accuracy. The standard chemical extraction procedures generally accepted are time consuming, require high amount of labour, chemicals and financial resources, and the application may contribute to the pollution of environment (RISTIC and FREUDENREICH, 2000). In addition to research, genetic evaluations in commercial practice need rapid on-line and non invasive procedures for different purposes (VAN LAACK et al., 2001; HOHENESTER, 2006).

The determination of the chemical composition of raw muscles and processed meat is based on analytical methods (ARNETH, 1998) and physical methods. The analytical methods use different solvents and solvent mixtures. The classic Soxhlet method is a widespread method, but nowadays efforts are made to lower the solvent use, and to minimise the time of analysis. Several automatic equipments are available at the market. Advantages of these are low solvent need and less labour and time requisite. There are also different physical methodologies for the estimation of the fat concentration in several tissues. It was reported the use of low field nuclear magnetic resonance (SØRLAND et al., 2004), the near-infrared analysis (VAN DEN NEUCKER et al., 2002), the computer image analysis (YANG et al., 2006), spectral analysis of ultrasound echo signals (CHAMBAZ et al., 2002; MÖRLEIN et al., 2005), or the impedance spectroscopy (ALTMANN and PLIQUETT, 2006) for the evaluation of the fat content.

The physical methods used in our laboratory are based on near infrared transmission (NIT) techniques and run without chemicals. All these physical methods need a calibration with the chemical extraction method. The measurements are based on the fact that protein, fat or moisture absorbs electromagnetic radiation in the near-infrared region of the spectrum. Both devices (Infratec1255 and FoodScan ${ }^{\mathrm{TM}}$ ) use transmission absorbance. The duration of these analyses is only few minutes.

The first aim of this study was to calculate the repeatability of different chemical and physical methods for the determination of the fat content in different tissues from cattle and pigs. The second objective was to evaluate the precision of the new $\mathrm{ANKOM}^{\mathrm{XT15}}$ Extractor device and the comparison to other chemical and physical methods. 
Materials and methods

\section{Meat samples}

The total fat content of 80 beef and pork cuts and tissues were analysed with different chemical and physical methods. Three chemical methods (classic Soxhlet; automatic extraction with petroleum ether; automatic extraction with petroleum ether after hydrolyzing), and two physical methods using NIT were included in this comparison (Table 1).

Table 1

Overview of tissues analysed and fat classes compared

(Überblick über die analysierten Gewebeproben und Einteilung in die Fettklassen)

\begin{tabular}{lccc}
\hline Tissues & & Number of samples & Groups $(\mathrm{G} 1,2,3)$ \\
\hline MLD beef & beef & 20 & 1 \\
MLD pork & pork & 23 & 1 \\
Tenderloin & beef & 3 & 2 \\
Tenderloin & pork & 2 & 2 \\
Ham & beef & 3 & 2 \\
Ham & pork & 2 & 2 \\
Chuck & beef & 3 & 2 \\
Blade steak & pork & 2 & 2 \\
Roast beef & beef & 3 & 2 \\
Loin & pork & 2 & 2 \\
Breast & beef & 5 & 3 \\
Belly and breast & pork & 5 & 3 \\
Head & pork & 5 & 3 \\
Hock & pork & 2 & \\
Total & & 80 & 2 \\
\hline
\end{tabular}

Group $1=$ muscles, fat content $0.5-3 \%$; group $2=$ carcass cuts, fat content $<15 \%$; group $3=$ carcass cuts with fat content $>15 \%$

\section{Analytical procedures compared}

In this investigation the total fat content of different cuts was determined with several methods as follows:

(1) extraction with Soxhlet method,

(2) extraction with automatic extraction system $\left(\mathrm{ANKOM}^{\mathrm{XT15}}\right.$ Extractor, ANKOM Technology, Macedon, USA),

(3) extraction with automatic extraction system, following hydrolysis $\left(\mathrm{ANKOM}^{\mathrm{HCL}}\right.$ Hydrolysis System and ANKOM ${ }^{\mathrm{XT15}}$ Extractor, ANKOM Technology, Macedon, USA),

(4) analysis with NIT method with Infratec equipment (Infratec1255 Food and Feed Analyzer, Tecator AB, Höganäs, Sweden),

(5) analysis with NIT method with Foss equipment (FoodScan ${ }^{\mathrm{TM}}$ Lab, FOSS Analytic, Hillerod, Danmark).

The fat contents of these 80 samples were very different. Therefore all samples were divided into three fat classes: group $1: 0.5-3 \%$ fat content $(n=43)$; group $2:<15 \%$ fat $(\mathrm{n}=25)$; group $3:>15 \%$ fat $(\mathrm{n}=12)$.

For the investigation $250 \mathrm{~g}$ muscle tissue or carcass cuts were taken, minced with a food processor (Multiboy, Ilmenau, Germany) and stored frozen $\left(-20^{\circ} \mathrm{C}\right)$ until analysis. For the comparison the samples were thawed at $4^{\circ} \mathrm{C}$ for $18 \mathrm{~h}$. The three chemical methods were carried out in threefold repetition. The results of the NIT method Infratec are the average of 10, and the results of the Foss method are the average of 16 measurements per sample. 
(1) Soxhlet method

With the Soxhlet method the moisture and the fat content were determined. A well defined and weighed amount (5-8 g) of the minced and well mixed samples was taken into an aluminium vessel, mixed with sea sand and ethanol. The samples were dried for $4 \mathrm{~h}$ at $105^{\circ} \mathrm{C}$ in a drying oven. The samples were then cooled to room temperature in an exsiccator, and weighed. The dry matter was calculated. The dried samples were then transferred into the Soxhlet equipment. The extraction was achieved with petroleum ether for $6 \mathrm{~h}$ at $60^{\circ} \mathrm{C}$. After the evaporation of the solvent, the flasks with the fat were dried for $1 \mathrm{~h}$ at $100^{\circ} \mathrm{C}$, and cooled to room temperature in desiccator and weighed. Intramuscular fat content (percentage) was calculated as follows:

Fat $(\%)=($ fat weight after extraction $\cdot 100) /$ wet sample

(2) Automatic extraction system (ANKOM ${ }^{\mathrm{XT15}}$ Extractor, ANKOM Technology, Macedon, USA)

This method determines crude fat by extraction with petroleum ether. The compounds extracted are predominantly triglycerides. A well defined and weighed amount (1-2 g) of the minced and well mixed samples in triplicates were taken, and placed into a filter bag weighed. The filter bag was encapsulated afterwards. The samples were then dried in a drying oven for $3 \mathrm{~h}$ at $102^{\circ} \mathrm{C}$. Then the dried samples were cooled in a desiccator to room temperature and weighed to get the water content of the samples. Up to 15 filter bags can be placed into the bag holder and then into the chamber of the ANKOM $^{\mathrm{XT15}}$ Extractor. Afterwards the automatic extraction was carried out for 60 $\min$ at $60^{\circ} \mathrm{C}$ with petroleum ether as extraction solvent. After the extraction the samples were dried for $30 \mathrm{~min}$ at $105^{\circ} \mathrm{C}$, cooled in desiccant pouch to room temperature and weighed.

Intramuscular fat percentage was calculated by the formula as follows:

$$
\text { Fat }(\%)=\left(W^{P D}-W^{E X}\right) \cdot 100 / W_{\text {sample }}
$$

where: $W^{P D}=$ pre-dried sample weight, $W^{E X}=$ dried sample weight after extraction, $W_{\text {sample }}=$ original weight of sample.

(3) Hydrolysis and automatic extraction system $\left(\mathrm{ANKOM}^{\mathrm{HCL}}\right.$ Hydrolysis System, ANKOM $^{\mathrm{X} 15}$ Extractor, ANKOM Technology, Macedon, USA)

Prior to the extraction the hydrolysis procedure has to be done. A well defined and weighted amount (1-1.5 g) of the minced samples was placed in a pre-weighted filter bag and closed. For high fat samples with $15 \%$ or more fat, a defined amount of filter aid (Kieselguhr 0.5-1 g; ratio 1:2 fat to filter) has to be added. Up to 20 filter bags can be placed in the chamber of the ANKOM Hydrolysis Instrument. The samples were then hydrolysed in $3 \mathrm{~N} \mathrm{HCL}$ for $90 \mathrm{~min}$ at $90^{\circ} \mathrm{C}$, and then rinsed for 4-6 times depending on the fat content. After the hydrolysis, the automatic extraction was carried out for $60 \mathrm{~min}$ at $60^{\circ} \mathrm{C}$ with petroleum ether as extraction solvent. Lipids were extracted from triplicate samples. After extraction the samples were dried for $30 \mathrm{~min}$ at $105^{\circ} \mathrm{C}$, cooled in desiccant pouch to room temperature and weighed. The fat content $(<15 \%)$ calculation was according to following equation:

$$
\text { Fat }(\%)=\left(W^{H Y}-W^{E X}\right) \cdot 100 / W_{\text {sample }}
$$

where: $W_{\text {sample }}=$ original weight of the sample, $W^{E X}=$ weight of the dried sample after extraction, $W^{H Y}=$ weight of the dried sample after hydrolysis. 
(4) Infratec1255 FFA-Analysator (Tekator AB, Höganäs, Sweden)

The NIT (Near Infrared Transmission) principle is based on the fact that the measured sample (raw meat) absorbs the near infrared light at different wavelengths according to different characteristics such as fat or protein content. It is an indirect method, which is based on a calibration on the classical chemical methods.

The Infratec1255 FFA is a NIT-analysis equipment. Fifty grams of the minced and well mixed samples are distributed in 5 cuvettes of the instrument. The equipment measures 2 times each cuvette. The instrument releases results which are the average of 10 measurements. The equipment has to be calibrated to Soxhlet method.

\section{(5) Foss FoodScan (FoodScan ${ }^{\mathrm{TM}}$ Lab, FOSS Analytic, Hillerod, Danmark)}

The Foss FoodScan is also a NIT based equipment. For this measurement 200-250 g of the minced and well mixed samples is extended into the analysis plate. The equipment measures 16 times. The results are the average of 16 measures. The equipment was calibrated to Soxhlet method.

\section{Statistical analysis}

For each method the fat content was estimated by the least-squares-mean method using the GLM procedures of the Statistical Analysis System (SAS ${ }^{\odot}$ Systems, Release 8.2, SAS Institute Inc., Cary, NC (SAS). Factors (method and fat content class) were considered in the analysis of variance. All statistical tests of Least Squared Means (LSM) were performed for a significance level $\alpha=0.05$. To calculate the repeatability $\theta$ of each method we used procedure VARCOMP of SAS ${ }^{\odot}$ to estimate the variance components $\sigma_{\text {sample }}^{2}$ and $\sigma_{\text {error }}^{2}\left(\theta=\sigma_{\text {sample }}^{2} /\left[\sigma_{\text {sample }}^{2}+\sigma_{\text {error }}^{2}\right]\right)$. The repeatability $\theta$ was calculated for all three chemical methods.

\section{Results}

In this investigation the fat content of different cuts of beef and pork were analysed with three different chemical and two physical methods. The cuts were ordered in groups with different fat content [group 1: longissimus muscles (fat content $0.5-3 \%$ ), group 2: tenderloin, ham, chuck, blade steak, roast beef, loin, breast (fat content $<15 \%$ ); group 3: belly and breast, head, hock (fat content $>15 \%$ )]. The numbers of samples analysed were in group 1, 2 and $3 n=43, n=25$, and 12, respectively.

As a measure of the reproducibility of the three chemical methods we used the coefficient of repeatability $(\theta)$ (see statistical analysis). The values of the repeatability for all three methods ranged between 0.88 and 1.00 representing in general a high reliability of the methods (Table 2).

In the fat group 1 and group 2 the Soxhlet method and in group 3 the ANKOM ${ }^{\mathrm{XT15}}$ method without hydrolysis reached the highest repeatability. Anyway, there are minimal differences among the repeatability results of the methods. By calculating the repeatability for all samples, the repeatability reached $\theta=0.99$ in all chemical methods. For both physical NIT measurements (FoodScan, Infratec) no repeatability could be established, because there were no single data available, only averages of measurements. 
Table 2

Repeatability $(\theta)$ of the different methods and fat groups

(Wiederholbarkeit [ $\theta$ ] der unterschiedlichen Methoden innerhalb der Fettklassen)

\begin{tabular}{cccc}
\hline & ANKOM $^{\mathrm{XT15}}$ & ANKOM $^{\mathrm{XT15} \& \mathrm{HCL}}$ & Soxhlet \\
\hline Group 1 & & & \\
$\mathrm{n}$ & 43 & 43 & 43 \\
$\theta$ & 0.98 & 0.99 & 1.00 \\
Group 2 & & 25 & 25 \\
$\mathrm{n}$ & 25 & 0.93 & 0.99 \\
$\theta$ & 0.94 & 12 & 12 \\
Group 3 & 12 & 0.88 & 0.95 \\
$\mathrm{n}$ & 0.98 & & \\
$\theta$ & & & \\
\hline
\end{tabular}

Table 3 shows the LSM and standard errors of the fat content (\%) of the three groups for all five different methods. In the group 1 the ANKOM and Soxhlet method estimated the highest fat content. In group 2 Soxhlet, ANKOM and Infratec methods supplied the highest intramuscular fat content. In the high fat group 3 there were no significant differences of the fat concentration measured by five methods.

Table 3

Fat content (\%) of different tissues determined with different methods (Fettgehalt [\%], mit unterschiedlichen Methoden ermittelt)

\begin{tabular}{|c|c|c|c|c|c|}
\hline & $\mathrm{ANKOM}^{\mathrm{XT15}}$ & $\mathrm{ANKOM}^{\mathrm{XT15} \& \mathrm{HCL}}$ & Soxhlet & FoodScan ${ }^{\mathrm{TM}} \mathrm{Lab}$ & INFRATEC1255 FFA \\
\hline \multicolumn{6}{|c|}{ Group 1} \\
\hline $\mathrm{n}$ & 43 & 43 & 43 & 43 & 43 \\
\hline LSM & 2. 42 & 2.02 & 2.41 & 2.27 & 2.24 \\
\hline SE & 0.33 & 0.33 & 0.33 & 0.34 & 0.34 \\
\hline \multicolumn{6}{|c|}{ Group 2} \\
\hline $\mathrm{n}$ & 25 & 25 & 25 & 25 & 25 \\
\hline LSM & 12.42 & 12.06 & 12.75 & 12.63 & 11.75 \\
\hline SE & 0.72 & 0.72 & 0.72 & 0.74 & 0.74 \\
\hline \multicolumn{6}{|c|}{ Group 3} \\
\hline $\mathrm{n}$ & 12 & 12 & 12 & 12 & 12 \\
\hline LSM & 43.16 & 43.02 & 43.30 & 42.23 & 44.77 \\
\hline SE & 2.23 & 2.23 & 2.23 & 2.30 & 2.30 \\
\hline
\end{tabular}

$\mathrm{n}=$ number of samples, LSM=least squared mean, $\mathrm{SE}=$ standard error

There were no statistical differences between the results measured by Soxhlet and $\mathrm{ANKOM}^{\mathrm{XT15}}$ method in all three fat groups. $\mathrm{ANKOM}^{\mathrm{XT15}}$ with hydrolysis and Infratec estimated in group 1 and 2 the lowest results. The Foss device had mostly similar results as the chemical methods. There are only significant differences between the two NIT techniques in the middle fat group 2. Table 4 contains the significant differences between the groups.

Table 4

Comparison of the differences between the LMS for different fat groups (G1, G2, G3) (Tukey-Kramer, $\mathrm{P}=0.05$ )

[Vergleich der Differenzen zwischen LSM für die drei Fettklassen (G1, G2, G3) (Tukey-Kramer, P=0.05)]

\begin{tabular}{lcccc}
\hline Methods & ANKOM $^{\mathrm{XT15}}$ & ANKOM $^{\mathrm{XT15} \& \mathrm{HCL}}$ & Soxhlet & FoodScan $^{\mathrm{TM}}$ Lab Infratec1255 FFA \\
\hline ANKOM $^{\mathrm{XT15}}$ & - & $\mathrm{G} 1$ & $\mathrm{G} 1, \mathrm{G} 2$ & $\mathrm{G} 2$ \\
ANKOM $^{\mathrm{XT15} \& \mathrm{HCL}}$ & & - & - & $\mathrm{G} 2$ \\
Soxhlet & & & $\mathrm{G} 2$ \\
FoodScan & & & - \\
Infratec1255 FFA & & & & - \\
\hline
\end{tabular}




\section{Discussion}

Particular attention has focused on the human health problems associated with the intake of fat and the fat composition in meat. On the other hand, intramuscular fat is widely regarded as an important trait affecting sensory characteristics of meat. Therefore, the accurate determination of fat concentration in muscle, meat cuts and products is very important. There are many physical techniques and chemical methods for the rapid analysis of fat. The criteria for selecting an analytical method are the precision, accuracy, reproducibility, simplicity, cost, speed, sensitivity, safety and also the official approval. The current study was conducted to test a new fat extraction device (ANKOM $^{\mathrm{XT15}}$ Extractor), to compare this with different chemical and physical methods and to find a rapid, environment-friendly, efficient and profitable analytical method for the fat determination in meat cuts and muscles of farm animals. The methods were carried out with samples of a wide range in fat content (0.3-60.57\%, see Table 5).

Table 5

Statistical measures of fat content estimated by different methods

(Statistische Maßzahlen des Fettgehaltes bestimmt mit unterschiedlichen Methoden)

\begin{tabular}{lccccc}
\hline & ANKOM $^{\mathrm{XT15}}$ & ANKOM $^{\mathrm{XT15} \& H C L}$ & Soxhlet & \multicolumn{2}{c}{ FoodScan } \\
\hline $\mathrm{nM}$ & Lab Infratec1255 FFA \\
LSM (\%) & 80 & 80 & 80 & 80 & 80 \\
Min & 11.65 & 11.31 & 11.77 & 11.50 & 11.59 \\
Max & 0.52 & 0.32 & 0.50 & 0.30 & 0.58 \\
SD & 56.61 & 55.23 & 56.44 & 55.62 & 60.57 \\
\hline
\end{tabular}

$\mathrm{n}=$ number of samples, $\mathrm{LSM}=$ least squared mean, $\mathrm{SD}=$ standard

All five methods were performed in parallel. As a measure of the reproducibility of the three chemical methods we used the coefficient of repeatability $\theta$. The value of the parameter $\theta>0.8$ represents the high reliability of a method (NUERNBERG et al., 2007). The results showed a very good accuracy and high reliability of all methods tested $(\theta$ range between $0.88-1.00)$. The lowest repeatability was found $\theta=0.885$ for the method ANKOM with hydrolysis. It should be considered, that a smaller amount of sample was taken by this method (1-1.5 g), in contrast to the Soxhlet method (5-8 g), and $\mathrm{ANKOM}^{\mathrm{XT15}}$ method $(2 \mathrm{~g})$. Nevertheless, the repeatability of the $\mathrm{ANKOM}^{\mathrm{XT15}}$ is high for all three fat groups investigated.

There were no statistical significant differences between the Soxhlet and ANKOM ${ }^{\mathrm{XT15}}$ method. Both methods based on the same principle of extraction, and were performed with the same solvent. If the hydrolysis proceeds the extraction with petroleum ether, the results are significantly lower $(\mathrm{P}<0.05)$ in group 1 (compared to Soxhlet and $\mathrm{ANKOM}^{\mathrm{XT15}}$ method) and group 2 (as compared to the Soxhlet method). These differences might be due to the hydrolysis.

Statistical significant differences were only measured in fat group 1 between ANKOM with hydrolysis and ANKOM and Soxhlet; in fat group 2 between Soxhlet and Infratec and ANKOM with hydrolysis, and Infratec and FoodScan and ANKOM with hydrolysis at $\mathrm{P}<0.05$. Results obtained by Infratec1255 in fat group 2 were significant lower compared to Soxhlet. Both NIT instruments are calibrated to the Soxhlet method. This has to be clarified in further measurements.

Explanation of variation between different methods might be due to definition of intramuscular fat and the solution of different fat classes (PIPEK et al., 2004). Intramuscular and intermuscular fat has to be separated and distinguished prior to 
subsequent extraction of fat. Even if different extraction methods were compared, variation among figures may occur. In the Soxhlet extraction method certain rest of triglycerides is not determined the proportion of components, e.g. cholesterol and phospholipids was the lowest when lean beef was analysed $82-89 \%$ of triglycerides was extracted and only a small amount of accompanying lipid components. In this current comparison only the extraction of fat with the neutral solvent petrol ether was used. To avoid interference of the connective tissue with the results of determination histological staining was recommended by ALBRECHT et al. (1996). The extraction by Soxhlet using non-polar n-hexane solvent might be considered an optimum for analysis of intramuscular fat in meat. ARNETH (1998) emphasizes that according to ISO 1444 the Soxhlet extraction is recommended as standard procedure for intramuscular fat content. In the study conducted by PIPEK, JELENIKOVA, and SARNOVSKY (2004) the Soxhlet method was compared to video image analysis LUCIA 3.52b (Laboratory Imaging, Prague) for intramuscular fat analysis in beef samples taken from Musculus longissimus lumborum and thoracis. Correlation coefficient estimated was $\mathrm{r}=0.99(\mathrm{P}<0.05)$. ALTMANN and PLIQUETT (2006) tested multiple multi-frequency impedance measurements. It has been expected that, the variability in impedance would correlate to the intramuscular fat due to inhomogeneous distribution of electrolytes and fat. Findings based on the comparative studies using beef and pork samples indicated that the selectivity of this method is not yet sufficient for practical use.

The advantage of the ANKOM technology compared to the classic Soxhlet method is the reduction of the extraction time ( $1 \mathrm{~h}$ compared to $6 \mathrm{~h}$, respectively). The $\mathrm{ANKOM}^{\mathrm{XT15}}$ Extractor works totally automatically and frees up human resources for other work, reduces solvent usage due to automatic solvent recycle and recovery. The repeatability is similar to that of the Soxhlet method. Hydrolysis before the extraction procedure with the ANKOM device did not improve the results. The ANKOM extraction procedure provides a rapid, high efficiency ( 15 samples at the same time) method for fat extraction in a shorter time, which reduces labour costs, reduces solvent consumption and has a good accuracy and precision. There were not identified any significant differences to the classic Soxhlet method. One further advantage is the price of the $\mathrm{ANKOM}^{\mathrm{XT15}}$ Extractor. The purchase of an $\mathrm{ANKOM}^{\mathrm{XT15}}$ instrument economically more optimal compared to other Soxhlet based instruments. Summarizing the results, the use of an $\mathrm{ANKOM}^{\mathrm{XT15}}$ Extractor can be recommended for the analyses of fat in muscle and meat.

\section{References}

ALBRECHT, E.; WEGNER, J.; ENDER, K.:

A new technique for objective evaluation of marbling in beef. Fleischwirtschaft 76 (1996), 1145-1147

ALTMANN, M.; PLIQUETT, U.:

Prediction of intramuscular fat by impedance spectroscopy. Meat Science 72 (2006), 4, 666-671.

ANTOSIK, K.; KRECIO, E.; ZYBERT, A.; SIECZKOWSKA, H.; KOCWIN-PODSIADLA, M.:

Comparison of two methods for estimation the chemical composition of porcine meat. Anim. Sci. Papers \& Reports. 24 (Suppl. 3), (2006), 9-14.

ARNETH; W.:

Chemisch-physikalische Analyse von Makroinhaltsstoffen. In: BRANSCHEID, W.; HONIKEL, K.- O., VON LENGERKEN, G.; TROEGER, K.: Qualität in Fleisch und Fleischwaren, Bd. 2, Frankfurt am Main (1998), 642-654 
BEJERHOLM, C.; BARTON-GADE, P.A.:

Effect of intramuscular fat level on eating quality of pig meat. $32^{\text {nd }}$ European Congress of Meat Research Workers, 24-26 August 1986, Ghent, Belgium

CHAMBAZ, A.; DUFEY, P.A.; KREUZER, M.; GRESHAM, J.:

Sources of variation influencing the use of real-time ultrasound to predict intramuscular fat in live beef cattle. Can. J. Anim. Sci. 82 (2002), 2, 133-139

HOHENESTER, S.CH.:

Evaluation of selected rapid methods for the determination of meat quality parameters. LudwigMaximilians-Universität, Tierärztliche Fakultät, Diss. München 2006 [in German]

LÜTJENS, A.; KALM, E.:

Zusammenhang zwischen analytischen und sensorischen Fleischbeschaffenheitsparametern.

MEYER, E.: Fleischwirtschaft 75 (1995), 484-491

Technologische und sensorische Bewertung der Fleischbeschaffenheit praktischer Mehrfachkreuzungen und Hybriden unter Berücksichtigung des intramuskulären Fettgehaltes. PhD-Thesis, Göttingen, 1991

MÖRLEIN, D.; ROSNER, F.; BRAND, S.; JENDERKA, K.-V.; WICKE, M.:

Non-destructive estimation of the intramuscular fat content of the longissimus muscle of pigs by means of spectral analysis of ultrasound echo signals. Meat Sci. 69 (2005), 187-199

NUERNBERG, K.; DANNENBERGER, D.; ENDER, K.; NUERNBERG, G.:

Comparison of different methylation methods for the analysis of conjugated linoleic acid isomers by silver ion HPLC in beef lipids. J. Agric. Food Chem. 55 (2007), 598-602

OKUMURA, T.; SAITO, K.; NADE, T.; MISUMI, S.; MASUDA, Y.; SAKUMA, H.; NAKAYAMA, S.;

FUJITA, K.; KAWAMURA, T.:

Effect of intramuscular fat on the sensory characteristics of M. longissimus dorsi in Japanese black steers as judged by a trained analytical panal. Asian-Australasian J. Anim. Sci. 20 (2007) 4, 577-581

PIPEK, P.; JELENIKOVA, J.; SARANOVSKY, L.:

The use of video image analysis for fat content estimation. Czech. J. Anim. Sci. 49 (2004) 3, 115-120

RISTIC, M.; FREUDENREICH, P.:

NIT-Schnellanalytik - dargestellt am Beispiel des Geflügelfleisches. Mitteilungsblatt der Bundesanstalt für Fleischforschung, Nr. 147 (2000), 551

SAS Statistical Analysis System, 1985

SEUSS-BAUM, I.:

Ernährungsphysiologische Bedeutung von Fleisch und Fleischerzeugnissen. In: BRANSCHEID, W.; HONIKEL, K.-O.; VON LENGERKEN, G.; TROEGER, K.: Qualität von Fleisch und Fleischwaren, Bd. 2, Frankfurt am Main (1998), 617-635

VAN LAACK, R.L.J.M.; STEVENS, S.G.; STAKDER, K.J.:

The influence of ultimate $\mathrm{pH}$ and intramuscular fat content on pork tenderness and tenderization. J. Anim. Sci. 79 (2001), 392-397

YANG, X.J.; ALBRECHT, E.; ENDER, K.; ZHAO, R.Q.; WEGNER, J.:

Computer image analysis of intramuscular adipocytes and marbling in the longissimus muscle of cattle. J. Anim. Sci. 84 (2006), 3251-3258

\author{
Received: 2008-07-8 \\ Accepted: 2008-07-15 \\ Corresponding author: \\ Dr. Karin Nuernberg \\ Research Institute for the Biology of Farm Animals \\ Wilhelm-Stahl-Allee 2 \\ 18196 Dummerstorf \\ Germany \\ email: knuernbg@fbn-dummerstorf.de
}

